\title{
Comparison of quality of life between 2-year and 3-or-more-year administration of leuprorelin acetate every-3-months depot in combination with tamoxifen as adjuvant endocrine treatment in premenopausal patients with endocrine-responsive breast cancer: a randomized controlled trial
}

\author{
Yasuo Ohashi ${ }^{1}$ - Eiichi Shiba ${ }^{2}$ - Hiroko Yamashita ${ }^{3,4}$ - Junichi Kurebayashi ${ }^{5}$. \\ Shinzaburo Noguchi ${ }^{6} \cdot$ Hirotaka Iwase $^{7} \cdot$ Michihiro Yoshida $^{8} \cdot$ Tsukasa Fujimoto $^{8}$
}

Received: 16 May 2016/Accepted: 2 October 2017 /Published online: 24 October 2017

(C) The Author(s) 2017. This article is an open access publication

\begin{abstract}
Background We conducted an open-label, randomized controlled trial evaluating the appropriate treatment duration of leuprorelin acetate 3-month depot, TAP-144-SR (3M), administered postsurgically every 3 months for 2 years versus 3 or more (up to 5) years, in combination with tamoxifen, for 5 years in premenopausal endocrine-responsive breast cancer patients and reported similar survival benefit in the two treatment groups. We hereby present patient-reported quality of life (QOL) data obtained from this trial.
\end{abstract}

A summary of this substudy has been presented at the poster session of the 14th St. Gallen International Breast Cancer Conference 2015.

Yasuo Ohashi

ohashiy.00e@g.chuo-u.ac.jp

1 Department of Integrated Science and Engineering for Sustainable Society, Chuo University, 1-13-27 Kasuga, Bunkyo-ku, Tokyo 112-8551, Japan

2 Department of Breast Surgery, Osaka Breast Clinic, Osaka, Japan

3 Department of Breast and Endocrine Surgery, Nagoya City University Hospital, Nagoya, Japan

4 Present address: Department of Breast Surgery, Hokkaido University Hospital, Sapporo, Japan

5 Department of Breast and Thyroid Surgery, Kawasaki Medical School, Kurashiki, Japan

6 Department of Breast and Endocrine Surgery, Osaka University Graduate School of Medicine, Osaka, Japan

7 Department of Breast and Endocrine Surgery, Kumamoto University, Kumamoto, Japan

8 Takeda Pharmaceutical Company Limited, Osaka, Japan
Methods Three self-administered QOL questionnaires (QOLACD, QOL-ACD-B, FACT-ES subscale) were used, and the difference in QOL score changes between the two groups was analyzed using a mixed-effects model for repeated measures. Results Eligible patients $(N=222)$ were randomly assigned to a 2-year (2YG, $N=112$ ) or 3-or-more-year treatment group ( $3 \mathrm{YG}, N=110$ ). The time courses of the three QOL scores during the trial period were similar in the two groups. The mean changes in the QOL scores from week 96 were largely stable through week 240 in the $3 \mathrm{YG}$, but showed significantly greater improvement in the score changes from week 96 in the 2 YG than the $3 Y$ G. Symptoms associated with menopause such as hot flashes and sweating contributed to these results. Menstruation recovery was associated with significantly greater improvement of these symptoms in the $2 \mathrm{YG}$ than the $3 \mathrm{YG}$.

Conclusions Patient-reported menopause-associated symptoms and QOL improved after discontinuation of the LHRH agonist administration and menstruation recovery. QOL information should be a consideration in long-term treatment.

Keywords Premenopausal endocrine-responsive breast cancer - Adjuvant endocrine therapy - Leuprorelin acetate . Luteinizing hormone-releasing hormone agonist · Quality of life

\section{Introduction}

Recently, it is well recognized that patients' physical and psychological well-being are as important as medical outcomes of 
cancer treatment, especially among young women with breast cancer [1-7]. The assessment of quality of life (QOL) using self-administered questionnaires provides accurate insights into patients' QOL status, such as physical and psychosocial well-being besides the impact of the cancer treatment itself, and offers invaluable information that is useful in decision-making processes concerning treatment options both for patients and clinicians [3-7]. For postoperative, premenopausal women with endocrineresponsive breast cancer, adjuvant endocrine therapy with more acceptable safety profiles and tolerability than adjuvant chemotherapy [8-10] is commonly used, indicating the potential efficacy of endocrine therapy to treat patients without compromising their QOL.

For the treatment of endocrine-responsive breast cancer in premenopausal women, it is of prime importance to suppress ovarian estrogen production through ovarian function suppression/ablation (OFS/OA). Currently, OFS with a luteinizing hormone-releasing hormone (LH-RH) agonist is widely used for 2 to 3 years as a postoperative adjuvant therapy in combination with tamoxifen for 5 years or chemotherapy in these patients [8-12]. A longer OFS with an LH-RH agonist for 5 years or longer is recommended for such patients at a high risk for recurrence [13]. At the St Gallen International Expert Consensus meetings, consensus was therefore reached on 5 years of tamoxifen alone or in combination with 5 years of an LH-RH agonist as the standard postoperative adjuvant therapy for premenopausal breast cancer patients [13-15].

Leuprorelin acetate (leuprorelin), an LH-RH agonist, is available as depot formulations (TAP-144-SR). It is commonly used worldwide for the treatment of hormone-responsive cancers, such as prostate cancer and premenopausal breast cancer. We recently conducted an open-label, randomized, controlled trial to evaluate the safety and efficacy of adjuvant therapy with TAP-144-SR (3M) administered every 3 months for 2 years versus 3 or more (up to 5) years, in combination with tamoxifen for 5 years in premenopausal women with endocrine-responsive breast cancer [16]. Adjuvant leuprorelin treatment for 3 or more years showed a similar survival benefit as treatment for 2 years, both in combination with tamoxifen, in premenopausal endocrine-responsive breast cancer patients. TAP-144-SR (3M) for 3 or more years was as well tolerated as TAP-144-SR (3M) for 2 years, and no new safety signals were identified for long-term TAP-144-SR (3M) treatment.

It is important to investigate patient-reported QOL in premenopausal breast cancer women receiving adjuvant hormone therapy, along with the acceptability of the treatment, which will provide a useful way of elucidating the risks and benefits of treatments $[5,6]$. We therefore compared the effect of two adjuvant treatment regimens on patient-reported QOL during the 5-year treatment period in the above trial.

\section{Patients and methods}

\section{Study design}

This was an open-label, randomized, controlled trial of adjuvant therapy with TAP-144-SR (3M) administered every 3 months for 2 years versus 3 or more (up to 5) years in combination with tamoxifen given daily for 5 years to evaluate the optimal duration of treatment with TAP-144-SR (3M) in postoperative, premenopausal women with endocrineresponsive breast cancer [16]. We also compared the impact of two treatment regimens on patients' QOL measured using three self-administered questionnaires during the 5-year treatment period in the above trial.

Patients and methods have previously been described in detail [16]. Briefly, eligible patients were randomly assigned at a 1:1 ratio to receive TAP-144-SR (3M) (11.25 mg) subcutaneous administration every 3 months either for 2 years or 3 or more (up to 5) years, in combination with tamoxifen $(20 \mathrm{mg}$ daily) given orally for 5 years. Random assignment was performed using dynamic allocation with the number of positive axillary lymph nodes $(0,1-3, \geq 4)$, tumor diameter $(\leq 2 \mathrm{~cm}$, $>2 \mathrm{~cm}$ ), estrogen receptor $(\mathrm{ER}) /$ progesterone receptor $(\mathrm{PgR})$ status $(\mathrm{ER}+/ \mathrm{PgR}+, \mathrm{ER}+/ \mathrm{PgR}-, \mathrm{ER}-/ \mathrm{PgR}+)$, age (at the time of enrollment; $\leq 39,40-44, \geq 45$ years), pre- and postoperative chemotherapy (presence, absence), and study site.

Patients assigned to the 2-year treatment group (2YG) received TAP-144-SR (3M) for 2 years (96 weeks) and tamoxifen for 5 years (240 weeks). In the 3-or-more-year treatment group (3YG), patients who completed 3-year (144 weeks) TAP-144-SR (3M) treatment could extend that treatment for up to 5 years ( 240 weeks in total) if it was considered appropriate, while tamoxifen was administered throughout the 5year trial period.

\section{Patients}

Patients were screened for eligibility according to the inclusion and exclusion criteria, which are described in the previous report [16]. Premenopausal patients with histologically confirmed primary breast cancer who met the following criteria were eligible for this trial: age $\geq 20$ years; ER+ and/ or PgR+ primary tumor; T1 to T3, any N, and M0, according to the TNM classification (Union for International Cancer Control, Sixth Edition, 2002); postoperative radiation of the breast in case of breast-conserving surgery; capable of receiving the trial drug and tamoxifen within 12 weeks after surgery or after postoperative adjuvant chemotherapy prior to enrollment; history of regular menstruation within 12 weeks prior to enrollment, or follicle-stimulating hormone (FSH) of $<40 \mathrm{mIU} / \mathrm{mL}$ and estradiol $\left(\mathrm{E}_{2}\right)$ of $\geq 10 \mathrm{pg} / \mathrm{mL}$ as measured within 12 weeks prior to enrollment; not having a chemical menopause within 12 weeks after completion of postoperative 
adjuvant chemotherapy; and performance status of grade 0 or 1.

Exclusion criteria included the following conditions or situations: endocrine therapy prior to surgery, postoperative adjuvant endocrine therapy before enrollment, bilateral oophorectomy and irradiation to bilateral ovaries, inflammatory breast cancer or bilateral breast cancer, and multiple cancers or a history of carcinoma in other organs.

\section{Endpoints}

As for QOL assessment, all participants were asked to fill out a self-administered QOL questionnaire form at randomization (baseline, week 0) and weeks 24, 48, 96, 144, 192, and 240. Changes in the QOL scores were measured using the following three questionnaires: (1) QOL Questionnaire for Cancer Patients Treated with Anticancer Drugs (QOL-ACD) comprising 22 items regarding daily activity, physical condition, psychological condition, and social attitude [17]; (2) QOLACD-Breast (QOL-ACD-B) comprising 18 items regarding physical condition, pain, satisfaction with medical treatment, coping with the disease, adverse reactions by treatment, and others [18]; and (3) Functional Assessment of Cancer Therapy-Endocrine Symptoms (FACT-ES) subscale comprising 19 items related to endocrine therapy [19]. A 5-point scale was used for each item.

The menstruation status was investigated for 36 weeks after the completion of treatment with TAP-144-SR (3M), even after the trial period.

\section{Statistical analysis}

Since this trial was a pilot trial, the sample size was determined considering feasibility; that is, we planned to enroll 220 patients (110 per group) [16].

The statistical analyses were performed on patients in the full analysis set (FAS), which was defined as all patients receiving at least one dose of the trial drug after randomization or those in the modified FAS (mFAS), which was defined as patients included in the FAS who were examined at the end of the second year of treatment (week 96) and then continued treatment in the trial.

The time courses of QOL scores during the trial period were summarized as mean and SD at each time point in FAS. For analysis of the change in each QOL score and each subordinate item score from week 96 in the mFAS, the two groups were compared using a mixed-effects model for repeated measures at weeks 144, 192, and 240 using the score at week 0 as the covariate. Cohen's $d$ was calculated for week 0 and also for each visit as a standardized mean effect size of $(2 \mathrm{YG}-3 \mathrm{YG}) /($ pooled SD) when the "group $\times$ visit interaction" or "difference between 2 groups in the main effect model" of repeated measures mixed model analysis was found to be significant. The Kaplan-Meier method was used to estimate the median menstruation recovery period from the last TAP-144-SR (3M) dosing. In addition, multiple regression analyses were applied to explore the relationships between the QOL subordinate item score changes and the patients' condition, including their menopausal status.

The significance level of statistical testing was set at 0.05 except for 0.10 for group by visit interaction (two-sided). Statistical analyses were conducted using SAS (version 9.2).

\section{Results}

\section{Patients}

A total of 222 patients were enrolled and randomly assigned to receive TAP-144-SR (3M) for either the two YG $(N=112)$ or the three YG $(N=110)$. Of 222 patients in the FAS, 196 patients (99 and 97, in the $2 \mathrm{YG}$ and $3 \mathrm{YG}$, respectively) completed the TAP-144-SR (3M) treatment, and 170 patients (81 and 89 , respectively) completed the 5 -year trial period. The median duration of the trial period was similar in the two treatment groups (1709 and 1711 days, respectively) [16].

Table 1 summarizes the baseline demographic and disease characteristics of patients in the FAS. The majority of patients had stage I (65.8\%), lymph node-negative (89.2\%), ER+/PR+ $(93.2 \%)$ breast cancer and did not receive postoperative chemotherapy $(89.6 \%)$. There were no significant differences in baseline characteristics between the groups except for serum $\mathrm{E}_{2}$ levels (Wilcoxon test, $p=0.033$ ) [16].

The majority of patients in both treatment groups had good medication compliance with the trial treatment: $99(88.4 \%)$ patients in the $2 \mathrm{YG}$ and $97(88.2 \%)$ patients in the $3 \mathrm{YG}$ received 8 and 12 or more doses of TAP-144-SR (3M) specified in the protocol, respectively. Most patients $(69.1 \%)$ in the 3 YG received 20 doses, the maximum number of doses in the trial. Each group had good adherence to tamoxifen treatment throughout the 5-year trial period [16].

\section{Quality of life}

The time courses of QOL scores measured using the three questionnaires were similar between the two treatment groups during the trial period (Fig. 1, QOL-ACD; data not shown). The mean changes in the QOL scores from week 96 were largely stable through week 240 in the 3 YG. Significantly greater improved score changes in the QOL-ACD-B score (total score of items 1 to 18) from week 96, however, were found in the $2 \mathrm{YG}$ than the $3 \mathrm{YG}$ (group $\times$ visit interaction, $p=0.017$ ), especially at week 192 [mean difference, 3.4 points; Cohen's $d$ (effect size), 0.43 ; visit-wise between-group contrast test in repeated measures mixed-effects model, $p=0.003$ ] and week 240 (3.0 points; $0.36 ; p=0.010)$ as 
Table 1 Baseline demographic and disease characteristics of patients

\begin{tabular}{|c|c|c|c|}
\hline \multirow[t]{2}{*}{ Variable } & \multirow{2}{*}{$\begin{array}{l}\text { Overall } \\
(N=222)\end{array}$} & \multicolumn{2}{|l|}{ Treatment group } \\
\hline & & $\begin{array}{l}2 \text { years }(N=112) n \\
(\%)\end{array}$ & $\begin{array}{l}3 \text { or more years }(N=110) n \\
(\%)\end{array}$ \\
\hline \multicolumn{4}{|l|}{ Age (years) } \\
\hline Median (range) & $43.0(25-56)$ & $43.5(25-52)$ & $43.0(27-56)$ \\
\hline \multicolumn{4}{|l|}{ BMI $\left(\mathrm{kg} / \mathrm{m}^{2}\right)$} \\
\hline Mean (SD) & $21.8(3.44)$ & $21.8(3.29)$ & $21.8(3.59)$ \\
\hline \multicolumn{4}{|c|}{ Tumor stage (TNM classification) } \\
\hline I & $146(65.8)$ & $74(66.1)$ & $72(65.5)$ \\
\hline IIA & $60(27.0)$ & $29(25.9)$ & $31(28.2)$ \\
\hline IIB-IIIB & $16(7.2)$ & $9(8.0)$ & $7(6.4)$ \\
\hline \multicolumn{4}{|l|}{ Tumor size $(\mathrm{cm})$} \\
\hline$\leq 2$ & $165(74.3)$ & $84(75.0)$ & $81(73.6)$ \\
\hline$>2$ & $57(25.7)$ & $28(25.0)$ & $29(26.4)$ \\
\hline \multicolumn{4}{|c|}{ Number of axillary lymph nodes } \\
\hline 0 & $198(89.2)$ & $100(89.3)$ & $98(89.1)$ \\
\hline $1-\max$ & $24(10.8)$ & $12(10.7)$ & $12(10.9)$ \\
\hline \multicolumn{4}{|l|}{ ER/PgR status } \\
\hline $\mathrm{ER}+/ \mathrm{PgR}+$ & $207(93.2)$ & $103(92.0)$ & $104(94.5)$ \\
\hline $\mathrm{ER}+/ \mathrm{PgR}-$ & $9(4.1)$ & $5(4.5)$ & $4(3.6)$ \\
\hline $\mathrm{ER}-/ \mathrm{PgR}+$ & $6(2.7)$ & $4(3.6)$ & $2(1.8)$ \\
\hline \multicolumn{4}{|l|}{ Preoperative chemotherapy } \\
\hline Presence & $4(1.8)$ & $2(1.8)$ & $2(1.8)$ \\
\hline Absence & $218(98.2)$ & $110(98.2)$ & $108(98.2)$ \\
\hline \multicolumn{4}{|c|}{ Postoperative chemotherapy } \\
\hline Presence & $23(10.4)$ & $12(10.7)$ & $11(10.0)$ \\
\hline Absence & $199(89.6)$ & $100(89.3)$ & $99(90.0)$ \\
\hline \multicolumn{4}{|c|}{ Serum $E_{2}(p g / m L)$ at week 0} \\
\hline $\begin{array}{l}\text { Median (interquartile } \\
\text { range) }\end{array}$ & $90.5(50.0-170.0)$ & $88.0(37.0-144.0)$ & $101.5(59.0-204.0)$ \\
\hline
\end{tabular}

Values represent the number $(\%)$ of patients unless otherwise indicated

$B M I$ body mass index, $E R$ estrogen receptor, $P g R$ progesterone receptor, $E_{2}$ estradiol shown in Fig. 2a. In addition, the mean changes in the FACTES subscale scores [except for the joint pain score (BRM1) based on the FACT-ES scoring guidelines version 4] from week 96 were significantly greater in the $2 \mathrm{YG}$ than the $3 \mathrm{YG}$ (group $\times$ visit interaction, $p=0.028$ ), especially at week 192 (2.5 points; $0.35 ; p=0.008$ ) (Fig. $2 b$ ).

To identify a subordinate item that significantly affects each QOL score, the mean changes in the QOL-ACD-B and FACT-ES subordinate items scores from week 96 were analyzed using a repeated measures mixed-effects model. The following subordinate items were found to be significantly different between groups in mean score changes from week 96: the QOL-ACD-B subordinate item 1, "Did you have any pain or numbness in your breast, armpit or arm on the side of illness?"; item 2, "Did you have any bloating in your arm on the side of the illness?"; item 8 , "Have you been satisfied with the facilities and staff, other than your doctor(s), at the hospital where you were diagnosed and/or treated?"; and item 13, "Were you bothered by hot flashes or sweating on your body or forehead?" (Table 2); FACT-ES subordinate item ES1, "I have hot flashes"; ES8, "I have pain or discomfort with intercourse"; and ES10, "I have gained weight" (Table 2). Especially, the subordinate items covering menopauseassociated symptoms such as hot flashes and sweating showed a significant and relatively large effect size [QOL-ACD-B subordinate item 13 (Cohen's $d, 0.34$ at week 144, 0.71 at week 192, and 0.58 at week 240); FACT-ES subordinate item ES1 (0.92 at week 192 and 0.49 at week 240)]. As a result of stratified analysis by age ( $\leq 44$ years, $\geq 45$ years) of these items as well as serum $\mathrm{E}_{2}$ levels and menstruation recovery, the effect size in the subpopulation aged $\leq 44$ years was 0.33 , 0.87, and 0.60 (QOL-ACD-B, item 13), and 0.38, 1.27, and 0.71 (FACT-ES, ES1) at weeks 144, 192, and 240, respectively. However, in the subpopulation aged $\geq 45$ years, it was 0.38 , 
Fig. 1 Time courses of a the Quality of Life Questionnaire for Cancer Patients Treated with Anticancer Drugs-Breast (QOLACD-B) score (total score of items 1 to 18 ) and $\mathbf{b}$ the Functional Assessment of Cancer Therapy-Endocrine Symptoms (FACT-ES) subscale score (except for BRM1) from week 0 to 240 (full analysis set). The FACT-ES subscale score is inverted according to the QOLACD-B score. Data indicate the mean + SD. SD, standard deviation a

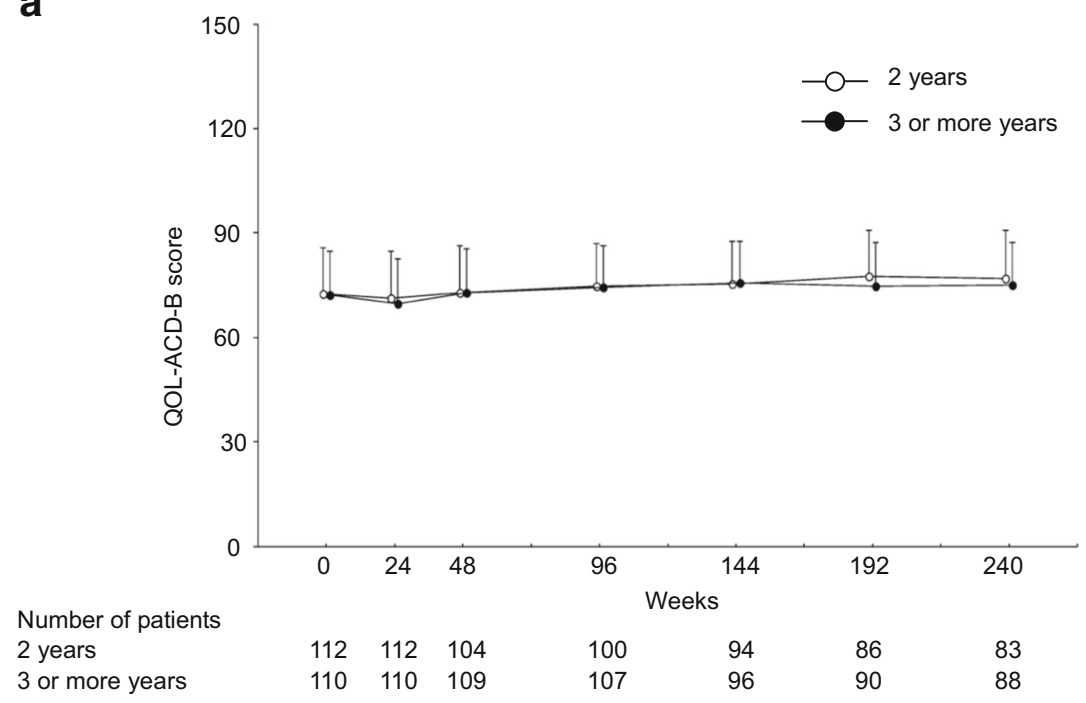

b

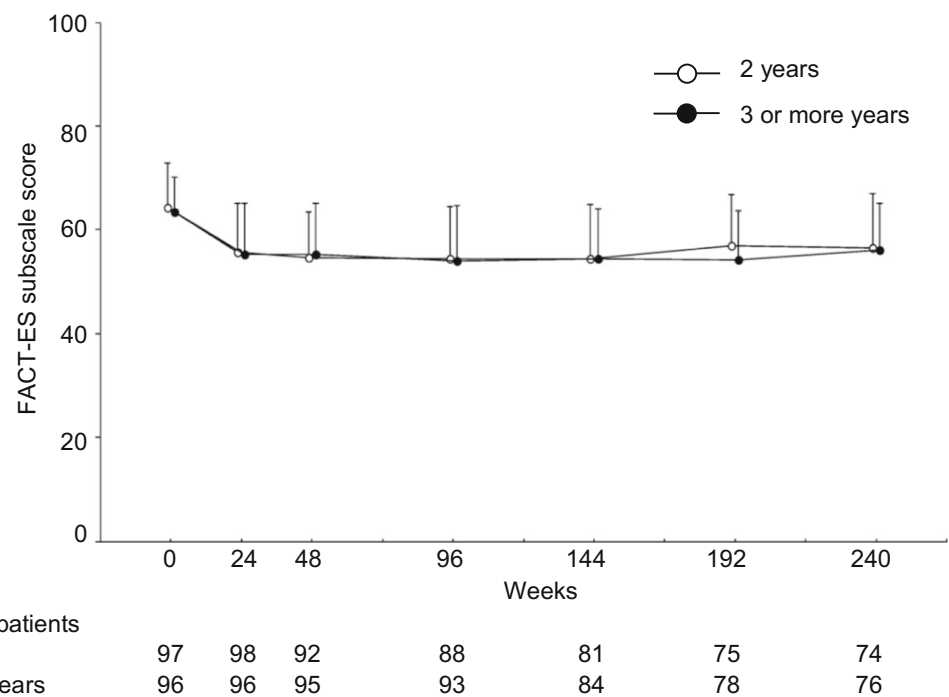

0.51, and 0.58 (QOL-ACD-B, item 13), and 0.16, 0.62, and 0.25 (FACT-ES, ES1), respectively (Table 2). The effect size was mostly greater in the subpopulation aged $\leq 44$ years than in that aged $\geq 45$ years at these time points.

\section{Serum $E_{2}$ level and menstruation recovery}

Serum $E_{2}$ levels significantly declined to menopausal levels $(<30 \mathrm{pg} / \mathrm{mL})$ after 12 weeks of TAP-144-SR $(3 \mathrm{M})$ treatment and remained suppressed through the completion of administration in both groups. In the $2 \mathrm{YG}$, serum $\mathrm{E}_{2}$ levels gradually increased after the completion of TAP-144-SR (3M) treatment and recovered to almost the same levels as the pretreatment values by week 132 [16]. By stratifying the patient population by age of " $\leq 44$ years" and " $\geq 45$ years" at the randomization point, for the subpopulation aged $\leq 44$ years in the $2 \mathrm{YG}$, the proportion of patients with menstruation recovery was $51 \%(25 / 49), 85 \%(39 / 46)$, and $74 \%(32 / 43)$ at weeks 144,192 , and 240 , respectively. In contrast, in the $3 \mathrm{YG}$, the proportion of patients with menstruation recovery was much smaller: $0 \%(0 / 55), 6 \%(3 / 49)$, and $15 \%(7 / 47)$ at the respective time points. Although the proportion of patients with menstruation recovery among those aged $\geq 45$ years in the $2 \mathrm{YG}$ was $24 \%$ (10/41), 33\% (13/39), and $37 \%(14 / 38)$ at weeks 144,192 , and 240 , respectively, no patients aged $\geq 45$ years in the $3 \mathrm{YG}$ had menstruation recovery at any time points (Fig. 3a). The rate of menstruation recovery was higher in the subpopulation aged $\leq 44$ years than $\geq 45$ years at these time points. The median time from last TAP-144-SR (3M) dosing to first menstruation recovery by the Kaplan-Meier estimation was 430 and 1078 days for the subpopulations aged $\leq 44$ and $\geq 45$ years, respectively, in the $2 \mathrm{YG}$, and 
a

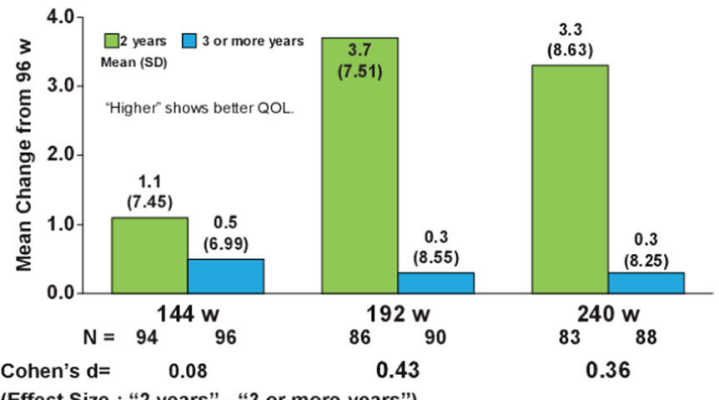

(Effect Size : "2 years" - "3 or more years")

Repeated measures mixed model analyses

\begin{tabular}{|c|c|c|c|c|}
\hline \multicolumn{4}{|c|}{ Group $\times$ Visit interaction model } & \multirow{2}{*}{$\begin{array}{c}\text { Main effect } \\
\text { model }\end{array}$} \\
\hline \multirow{2}{*}{$\begin{array}{l}\text { Group } \times \\
\text { Visit } \\
\text { interaction }\end{array}$} & \multicolumn{3}{|c|}{$\begin{array}{c}\text { Between-group comparison } \\
\text { per visit }\end{array}$} & \\
\hline & $144 \mathrm{w}$ & $192 \mathrm{w}$ & $240 w$ & $\begin{array}{l}\text { Between } \\
\text { group }\end{array}$ \\
\hline$p=0.017$ & $p=0.577$ & $p=0.003$ & $p=0.010$ & $p=0.073$ \\
\hline
\end{tabular}

Fig. 2 The change of the Quality of Life (QOL) Questionnaire for Cancer Patients Treated with Anticancer Drugs-Breast (QOL-ACD-B) score and the Functional Assessment of Cancer Therapy-Endocrine Symptoms (FACT-ES) subscale score from week 96. a QOL-ACD-B

427 days and undeterminable for those aged $\leq 44$ and $\geq 45$ years, respectively, in the $3 \mathrm{YG}$ (Fig. $3 \mathrm{~b}$ ). The distribution of the recovery period was similar between the two groups for the subpopulation aged $\leq 44$ years, although the number of patients with menses recovery was much smaller in the $3 \mathrm{YG}$ due to the shorter duration of the total menstruation follow-up period (trial period after the last dosing and follow-up observation period) than the 2 YG.

\section{Relationship between QOL subordinate item score changes and patients' status}

In order to explore the relationships between the QOL subordinate item score changes (QOL-ACD-B subordinate item 13 and FACT-ES subordinate item ES1) and patients' status, including menopausal status, multiple regression analysis was performed using the mean score changes from week 96 in these subordinate items at weeks 144, 192, and 240 as dependent variables, and four factors [the treatment group, the age at the time of randomization (week 0), the corresponding QOL subordinate item scores at week 96 , and the menstruation (presence/absence) at each assessment point] as independent variables. The results strongly suggested that in both QOLACD-B (item 13) and FACT-ES (ES 1), the QOL subordinate item at week 96 and the presence of menstruation at each assessment point had large standardized partial regression coefficients with change of corresponding QOL subordinate item scores at weeks 144, 192, and 240 ( $p<0.001$ for each) (Fig. 4).

\section{b}

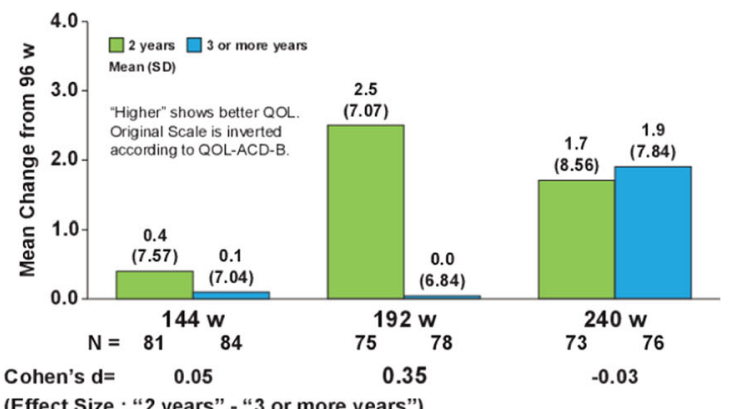

(Effect Size : " 2 years" - " 3 or more years")

\begin{tabular}{|c|c|c|c|c|}
\hline \multicolumn{4}{|c|}{ Group $\times$ Visit interaction model } & \multirow{3}{*}{$\begin{array}{c}\begin{array}{c}\text { Main effect } \\
\text { model }\end{array} \\
\begin{array}{c}\text { Between } \\
\text { group }\end{array}\end{array}$} \\
\hline \multirow{2}{*}{$\begin{array}{l}\text { Group } \times \\
\text { Visit } \\
\text { interaction }\end{array}$} & \multicolumn{3}{|c|}{$\begin{array}{c}\text { Between-group comparison } \\
\text { per visit } \\
\end{array}$} & \\
\hline & $144 w$ & $192 w$ & $240 w$ & \\
\hline$p=0.028$ & $p=0.612$ & $p=0.008$ & $p=0.496$ & $p=0.060$ \\
\hline
\end{tabular}

score (total score of items 1 to 18). b FACT-ES subscale score (except for BRM1). $N$ number of patients evaluated, $144 w$ week $144,192 w$ week 192, $240 w$ week 240, SD standard deviation

\section{Discussion}

The primary objective of this open-label, randomized, controlled trial of TAP-144-SR (3M) administered every 3 months for 2 years versus 3 or more (up to 5) years, in combination with tamoxifen given daily for 5 years, was to investigate the appropriate treatment duration of LH-RH agonists in premenopausal women with endocrine-responsive breast cancer. In this trial, we also compared the effect of two treatment regimens on patient-reported QOL. The time courses of QOL scores measured using the three QOL questionnaires (QOLACD, QOL-ACD-B, FACT-ES subscale) were similar between the two treatment groups (Fig. 1). The mean changes in the QOL scores from week 96 were largely stable through week 240 in the $3 \mathrm{YG}$. However, significantly greater improvement in the score changes from week 96 was found in the 2 YG than the 3YG: QOL-ACD-B score (total score of items 1 to 18) at weeks 192 and 240 (Fig. 2a), and FACT-ES subscale score (except the joint pain score) at week 192 (Fig. 2b).

The subordinate items indicating menopause-associated symptom burden such as hot flashes and sweating (i.e., QOL-ACD-B subordinate item 13 and FACT-ES subordinate item ES1) were shown to significantly improve in the $2 \mathrm{YG}$ compared to the $3 \mathrm{YG}$ in the mixed-effects model of repeated measures (Table 2). On the other hand, the exploratory multiple regression analysis indicated the great contribution of menstruation (presence/absence) at each time point and the corresponding QOL subordinate item scores at week 96 to 
Table 2 QOL-ACD-B and FACT-ES subordinate items in repeated measures mixed model analyses and the stratification analyses

\begin{tabular}{|c|c|c|c|c|c|c|}
\hline \multirow[t]{4}{*}{ Item $^{\mathrm{a}}$} & \multirow{4}{*}{$\begin{array}{l}\text { Baseline } \\
\text { Week } 0^{\mathrm{c}}\end{array}$} & \multicolumn{5}{|c|}{ Repeated measures mixed model analysis ${ }^{\mathrm{b}}$} \\
\hline & & \multicolumn{4}{|c|}{ Group $\times$ visit interaction model } & \multirow{3}{*}{$\begin{array}{l}\begin{array}{l}\text { Main } \\
\text { effect } \\
\text { model }\end{array} \\
\begin{array}{l}\text { Between } \\
\text { the } \\
\text { groups }\end{array}\end{array}$} \\
\hline & & \multirow{2}{*}{$\begin{array}{l}\text { Group } \times \text { visit } \\
\text {-interaction }\end{array}$} & \multicolumn{3}{|c|}{ Between-group comparison per visit ${ }^{\mathrm{d}}$} & \\
\hline & & & Week 144 & Week 192 & Week 240 & \\
\hline \multicolumn{7}{|l|}{ QOL-ACD-B } \\
\hline $\begin{array}{l}\text { 1. Did you have any } \\
\text { pain or numbness in } \\
\text { your breast, armpit } \\
\text { or arm on the side of } \\
\text { illness? }\end{array}$ & $\begin{array}{l}p=0.567 \\
(-0.08)\end{array}$ & $p=0.040$ & $\begin{array}{l}p=0.703 \\
(0.07)\end{array}$ & $\begin{array}{l}p=0.007 \\
(0.39)\end{array}$ & $\begin{array}{l}p=0.195 \\
(0.17)\end{array}$ & $p=0.096$ \\
\hline $\begin{array}{l}\text { 2. Did you have any } \\
\text { bloating in your arm } \\
\text { on the side of the } \\
\text { illness? }\end{array}$ & $\begin{array}{l}p=0.250 \\
(-0.16)\end{array}$ & $p=0.076$ & $\begin{array}{l}p=0.187 \\
(0.19)\end{array}$ & $\begin{array}{l}p=0.237 \\
(0.19)\end{array}$ & $\begin{array}{l}p=0.003 \\
(0.49)\end{array}$ & $p=\mathbf{0 . 0 3 2}$ \\
\hline $\begin{array}{l}\text { 3. Were you able to } \\
\text { raise your arm } \\
\text { completely on the } \\
\text { side of the illness? }\end{array}$ & $\begin{array}{l}p=0.095 \\
(-0.24)\end{array}$ & $p=0.581$ & $p=0.933$ & $p=0.457$ & $p=0.978$ & $p=0.848$ \\
\hline $\begin{array}{l}\text { 4. Did you worry } \\
\text { about skin problems } \\
\text { (redness, swelling, } \\
\text { hot flashes, } \\
\text { itchiness, etc.) at the } \\
\text { area of your breast } \\
\text { on the side of the } \\
\text { illness? }\end{array}$ & $\begin{array}{l}p=0.886 \\
(0.02)\end{array}$ & $p=0.189$ & $p=0.705$ & $p=0.106$ & $p=0.040$ & $p=0.164$ \\
\hline $\begin{array}{l}\text { 5. Did you have any } \\
\text { pain associated with } \\
\text { your illness or } \\
\text { treatment? }\end{array}$ & $\begin{array}{l}p=0.938 \\
(-0.01)\end{array}$ & $p=0.151$ & $p=0.376$ & $p=0.014$ & $p=0.245$ & $p=0.078$ \\
\hline $\begin{array}{l}\text { 6. (Answer this } \\
\text { question only if you } \\
\text { have had } \\
\text { operations.) }\end{array}$ & $\begin{array}{l}p=0.990 \\
(0.00)\end{array}$ & $p=0.438$ & $p=0.852$ & $p=0.243$ & $p=0.711$ & $p=0.669$ \\
\hline \multicolumn{7}{|l|}{$\begin{array}{l}\text { Have you been satisfied } \\
\text { with the appearance } \\
\text { of your breast (and/or } \\
\text { scar)? }\end{array}$} \\
\hline $\begin{array}{l}\text { 7. Have you been } \\
\text { satisfied with the } \\
\text { explanation you } \\
\text { have received from } \\
\text { your doctor(s) } \\
\text { about your } \\
\text { condition and/or } \\
\text { treatment? }\end{array}$ & $\begin{array}{l}p=0.632 \\
(0.07)\end{array}$ & $p=0.883$ & $p=0.429$ & $p=0.480$ & $p=0.764$ & $p=0.442$ \\
\hline $\begin{array}{l}\text { 8. Have you been } \\
\text { satisfied with the } \\
\text { facilities and staff, } \\
\text { other than your } \\
\text { doctor(s), at the } \\
\text { hospital where you } \\
\text { were diagnosed } \\
\text { and/or treated? }\end{array}$ & $\begin{array}{l}p=0.216 \\
(0.18)\end{array}$ & $p=0.058$ & $\begin{array}{l}p=0.216 \\
(0.21)\end{array}$ & $\begin{array}{l}p=0.213 \\
(-0.19)\end{array}$ & $\begin{array}{l}p=0.593 \\
(0.07)\end{array}$ & $p=0.691$ \\
\hline $\begin{array}{l}\text { 9. Do you feel that } \\
\text { you have } \\
\text { adequately accepted }\end{array}$ & $\begin{array}{l}p=0.988 \\
(0.00)\end{array}$ & $p=0.405$ & $p=0.445$ & $p=0.224$ & $p=0.997$ & $p=0.547$ \\
\hline
\end{tabular}
your illness? 
Table 2 (continued)

\begin{tabular}{|c|c|c|c|c|c|c|}
\hline \multirow[t]{4}{*}{ Item $^{\mathrm{a}}$} & \multirow{4}{*}{$\begin{array}{l}\text { Baseline } \\
\text { Week } 0^{\mathrm{c}}\end{array}$} & \multicolumn{5}{|c|}{ Repeated measures mixed model analysis ${ }^{\mathrm{b}}$} \\
\hline & & \multicolumn{4}{|c|}{ Group $\times$ visit interaction model } & \multirow{3}{*}{$\begin{array}{l}\begin{array}{l}\text { Main } \\
\text { effect } \\
\text { model }\end{array} \\
\text { Between } \\
\text { the } \\
\text { groups }\end{array}$} \\
\hline & & \multirow{2}{*}{$\begin{array}{l}\text { Group } \times \text { visit } \\
\text {-interaction }\end{array}$} & \multicolumn{3}{|c|}{ Between-group comparison per visit ${ }^{\mathrm{d}}$} & \\
\hline & & & Week 144 & Week 192 & Week 240 & \\
\hline $\begin{array}{l}\text { 10. Have you been } \\
\text { determined to fight } \\
\text { your illness? }\end{array}$ & $\begin{array}{l}p=0.540 \\
(-0.09)\end{array}$ & $p=0.929$ & $p=0.637$ & $p=0.581$ & $p=0.451$ & $p=0.488$ \\
\hline $\begin{array}{l}\text { 12. Have you suffered } \\
\text { from fatigue? }\end{array}$ & $\begin{array}{l}p=0.549 \\
(0.08)\end{array}$ & $p=0.364$ & $p=0.654$ & $p=0.590$ & $p=0.320$ & $p=0.894$ \\
\hline $\begin{array}{l}\text { 13. Were you } \\
\text { bothered by hot } \\
\text { flashes or sweating } \\
\text { on your body or } \\
\text { forehead? }\end{array}$ & $\begin{array}{l}p=0.154 \\
(-0.20)\end{array}$ & $p=0.047$ & $\begin{array}{l}p=0.018 \\
(0.34)\end{array}$ & $\begin{array}{l}p<0.001 \\
(0.71)\end{array}$ & $\begin{array}{l}p=0.001 \\
(0.58)\end{array}$ & $p=0.001$ \\
\hline Age $\leq 44$ years & $\begin{array}{l}p=0.068 \\
(-0.35)\end{array}$ & $p=0.013$ & $\begin{array}{l}p=0.093 \\
(0.33)\end{array}$ & $\begin{array}{l}p<0.001 \\
(0.87)\end{array}$ & $\begin{array}{l}p=0.016 \\
(0.60)\end{array}$ & $p=0.015$ \\
\hline Age $\geq 45$ years & $\begin{array}{l}p=1.000 \\
(0.00)\end{array}$ & $p=0.484$ & $\begin{array}{l}p=0.075 \\
(0.38)\end{array}$ & $\begin{array}{l}p=0.030 \\
(0.51)\end{array}$ & $\begin{array}{l}p=0.011 \\
(0.58)\end{array}$ & $p=0.017$ \\
\hline $\begin{array}{l}\text { 18. Were you } \\
\text { concerned that } \\
\text { other members of } \\
\text { your family would } \\
\text { suffer from the } \\
\text { same illness? } \\
\text { FACT-ES }\end{array}$ & $\begin{array}{l}p=0.933 \\
(-0.01)\end{array}$ & $p=0.380$ & $p=0.465$ & $p=0.589$ & $p=0.037$ & $p=0.094$ \\
\hline $\begin{array}{l}\text { ES1. I have hot } \\
\text { flashes. }\end{array}$ & $\begin{array}{l}p=0.137 \\
(-0.23)\end{array}$ & $p<0.001$ & $\begin{array}{l}p=0.118 \\
(0.27)\end{array}$ & $\begin{array}{l}p<0.001 \\
(0.92)\end{array}$ & $\begin{array}{l}p=0.001 \\
(0.49)\end{array}$ & $p<0.001$ \\
\hline Age $\leq 44$ years & $\begin{array}{l}p=0.036 \\
(-0.44)\end{array}$ & $p<0.001$ & $\begin{array}{l}p=0.134 \\
(0.38)\end{array}$ & $\begin{array}{l}p<0.001 \\
(1.27)\end{array}$ & $\begin{array}{l}p=0.001 \\
(0.71)\end{array}$ & $p<0.001$ \\
\hline Age $\geq 45$ years & $\begin{array}{l}p=0.809 \\
(0.05)\end{array}$ & $p=0.039$ & $\begin{array}{l}p=0.488 \\
(0.16)\end{array}$ & $\begin{array}{l}p=0.009 \\
(0.62)\end{array}$ & $\begin{array}{l}p=0.243 \\
(0.25)\end{array}$ & $p=0.158$ \\
\hline ES2. I have sweats. & $\begin{array}{l}p=0.842 \\
(-0.03)\end{array}$ & $p=0.196$ & $p=0.222$ & $p=0.017$ & $p=0.092$ & $p=0.089$ \\
\hline $\begin{array}{l}\text { ES3. I have night } \\
\text { sweats. }\end{array}$ & $\begin{array}{l}p=0.234 \\
(0.18)\end{array}$ & $p=0.391$ & $p=0.886$ & $p=0.302$ & $p=0.324$ & $p=0.568$ \\
\hline $\begin{array}{l}\text { ES4. I have vaginal } \\
\text { discharge. }\end{array}$ & $\begin{array}{l}p=0.284 \\
(0.16)\end{array}$ & $p=0.425$ & $p=0.893$ & $p=0.775$ & $p=0.421$ & $p=0.755$ \\
\hline $\begin{array}{l}\text { ES5. I have vaginal } \\
\text { itching/irritation. }\end{array}$ & $\begin{array}{l}p=0.834 \\
(-0.03)\end{array}$ & $p=0.119$ & $p=0.077$ & $p=0.918$ & $p=0.675$ & $p=0.317$ \\
\hline $\begin{array}{l}\text { ES6. I have vaginal } \\
\text { bleeding or } \\
\text { spotting. }\end{array}$ & $\begin{array}{l}p=0.179 \\
(0.21)\end{array}$ & $p=0.632$ & $p=0.387$ & $p=0.547$ & $p=0.169$ & $p=0.291$ \\
\hline $\begin{array}{l}\text { ES7. I have vaginal } \\
\text { dryness. }\end{array}$ & $\begin{array}{l}p=0.099 \\
(-0.25)\end{array}$ & $p=0.988$ & $p=0.654$ & $p=0.582$ & $p=0.647$ & $p=0.574$ \\
\hline $\begin{array}{l}\text { ES8. I have pain or } \\
\text { discomfort with } \\
\text { intercourse. }\end{array}$ & $\begin{array}{l}p=0.537 \\
(-0.10)\end{array}$ & $p=0.919$ & $\begin{array}{l}p=0.051 \\
(0.31)\end{array}$ & $\begin{array}{l}p=0.048 \\
(0.37)\end{array}$ & $\begin{array}{l}p=0.033 \\
(0.38)\end{array}$ & $p=0.016$ \\
\hline Age $\leq 44$ years & $\begin{array}{l}p=0.675 \\
(-0.09)\end{array}$ & $p=0.744$ & $p=0.190$ & $p=0.129$ & $p=0.061$ & $p=0.068$ \\
\hline Age $\geq 45$ years & $\begin{array}{l}p=0.660 \\
(-0.11)\end{array}$ & $p=0.992$ & $p=0.118$ & $p=0.190$ & $p=0.211$ & $p=0.088$ \\
\hline $\begin{array}{l}\text { ES9. I have lost } \\
\text { interest in sex. }\end{array}$ & $\begin{array}{l}p=0.524 \\
(0.10)\end{array}$ & $p=0.633$ & $p=0.942$ & $p=0.363$ & $p=0.743$ & $p=0.577$ \\
\hline
\end{tabular}


Table 2 (continued)

\begin{tabular}{|c|c|c|c|c|c|c|}
\hline \multirow[t]{4}{*}{ Item $^{\mathrm{a}}$} & \multirow{4}{*}{$\begin{array}{l}\text { Baseline } \\
\text { Week } 0^{c}\end{array}$} & \multicolumn{5}{|c|}{ Repeated measures mixed model analysis ${ }^{\mathrm{b}}$} \\
\hline & & \multicolumn{4}{|c|}{ Group $\times$ visit interaction model } & \multirow{3}{*}{$\begin{array}{l}\begin{array}{l}\text { Main } \\
\text { effect } \\
\text { model }\end{array} \\
\text { Between } \\
\text { the } \\
\text { groups }\end{array}$} \\
\hline & & \multirow{2}{*}{$\begin{array}{l}\text { Group } \times \text { visit } \\
\text {-interaction }\end{array}$} & \multicolumn{3}{|c|}{ Between-group comparison per visit ${ }^{\mathrm{d}}$} & \\
\hline & & & Week 144 & Week 192 & Week 240 & \\
\hline $\begin{array}{l}\text { ES10. I have gained } \\
\text { weight. }\end{array}$ & $\begin{array}{l}p=0.564 \\
(0.09)\end{array}$ & $p=0.025$ & $\begin{array}{l}p=0.646 \\
(-0.08)\end{array}$ & $\begin{array}{l}p=0.074 \\
(0.19)\end{array}$ & $\begin{array}{l}p=0.791 \\
(0.01)\end{array}$ & $p=0.873$ \\
\hline $\begin{array}{l}\text { An9. I feel } \\
\text { lightheaded (dizzy). }\end{array}$ & $\begin{array}{l}p=0.874 \\
(0.02)\end{array}$ & $p=0.179$ & $p=0.861$ & $p=0.164$ & $p=0.672$ & $p=0.695$ \\
\hline $\begin{array}{l}\text { O2. I have been } \\
\text { vomiting. }\end{array}$ & $\begin{array}{l}p=0.186 \\
(0.20)\end{array}$ & $p=0.189$ & $p=0.988$ & $p=0.776$ & $p=0.178$ & $p=0.796$ \\
\hline C5. I have diarrhea. & $\begin{array}{l}p=0.432 \\
(0.12)\end{array}$ & $p=0.723$ & $p=0.855$ & $p=0.825$ & $p=0.444$ & $p=0.583$ \\
\hline $\begin{array}{l}\text { An10. I get } \\
\text { headaches. }\end{array}$ & $\begin{array}{l}p=0.307 \\
(0.16)\end{array}$ & $p=0.211$ & $p=0.600$ & $p=0.138$ & $p=0.643$ & $p=0.392$ \\
\hline Tax1. I feel bloated. & $\begin{array}{l}p=0.328 \\
(0.15)\end{array}$ & $p=0.239$ & $p=0.167$ & $p=0.825$ & $p=0.813$ & $p=0.553$ \\
\hline $\begin{array}{l}\text { ES11. I have breast } \\
\text { sensitivity/- } \\
\text { tenderness. }\end{array}$ & $\begin{array}{l}p=0.065 \\
(0.28)\end{array}$ & $p=0.772$ & $p=0.682$ & $p=0.257$ & $p=0.236$ & $p=0.271$ \\
\hline $\begin{array}{l}\text { ES12. I have mood } \\
\text { swings. }\end{array}$ & $\begin{array}{l}p=0.136 \\
(0.23)\end{array}$ & $p=0.561$ & $p=0.343$ & $p=0.988$ & $p=0.851$ & $p=0.672$ \\
\hline ES13. I am irritable. & $\begin{array}{l}p=0.953 \\
(-0.01)\end{array}$ & $p=0.828$ & $p=0.516$ & $p=0.319$ & $p=0.581$ & $p=0.416$ \\
\hline $\begin{array}{l}\text { BM1. I have pain in my } \\
\text { joints. }\end{array}$ & $\begin{array}{l}p=0.571 \\
(-0.09)\end{array}$ & $p=0.145$ & $p=0.482$ & $p=0.386$ & $p=0.384$ & $p=0.767$ \\
\hline
\end{tabular}

Bold $p \leq 0.05$ except for $p \leq 0.10$ for group by visit interaction (2-sides)

${ }^{\mathrm{a}}$ Individual analysis was not separately performed for items 11 and 14 to 17 of QOL-ACD-B due to the lower response rate to the items

- item11: Have you experienced hair loss?

- item14: Were you bothered by any change (trouble) in ways you taste foods?

- item15: Did you feel any inconvenience because you were unable to choose clothes that you wanted to wear?

- item16: Do you feel reluctant to disrobe in the presence of other people, such as at a spa?

- item17: Are you satisfied with your sex life?

${ }^{\mathrm{b}}$ Repeated measures mixed-effects model analysis: the model analysis was applied to the change in each QOL score at weeks 144, 192, and 240 from week 96 using the baseline (week 0) as the covariate in the mFAS

${ }^{\mathrm{c}}$ The two-sample $t$ test $p$ value and Cohen's $d$ statistics in the parenthesis were for "between-group difference in the week 0 QOL score"

${ }^{\mathrm{d}}$ Model analysis $p$ value and Cohen's $d$ statistics: Cohen's $d$ was estimated for "between-group differences in QOL changes at weeks 144, 192, and 240 from week 96," only when the "group $\times$ visit interaction" or "difference between 2 groups in the main effect model" was found to be significant

the QOL improvement, and that there was no significant group difference after adjustment for these two factors (Fig. 4). The results could be interpreted as that the significant group difference of QOL improvement is almost explained by the recovery of menstruation after the completion of TAP-144-SR (3M) and some severity of hot flashes and sweating burden at week 96, and that the treatment group difference shows no significant additional impact on QOL improvement associated with any other unexplained factors.
In this trial, approximately $90 \%$ of patients in each group did not receive postoperative chemotherapy, which makes recovery of menstruation more likely. Menstruation recovery after completion of treatment was seen in more patients in the $2 \mathrm{YG}$ than the $3 \mathrm{YG}$, particularly in the patient population aged $\leq 44$ years in the 2 YG at weeks 192 and 240 (Fig. 3a). Since the results of stratification by age of the above QOL subordinate items associated with hot flashes and sweating indicated greater improvement in the subpopulation aged 
a

\section{2 years}

Age at 0 w: 44 or less

Visits Menstruation E2 Histgram

$144 w$
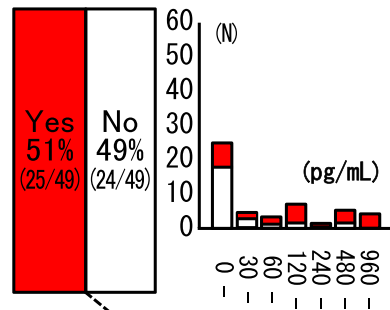

$192 w$
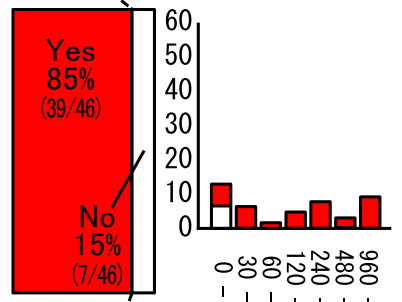

$240 w$
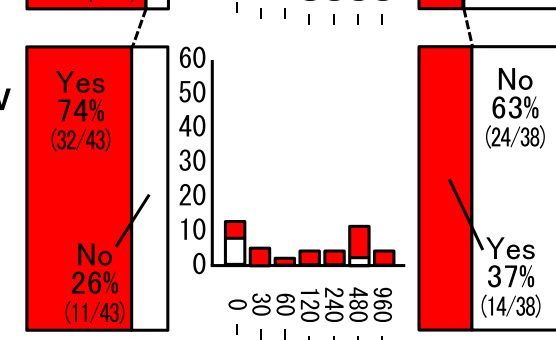

Age at 0 w: 45 or more

Menstruation E2 Histgram
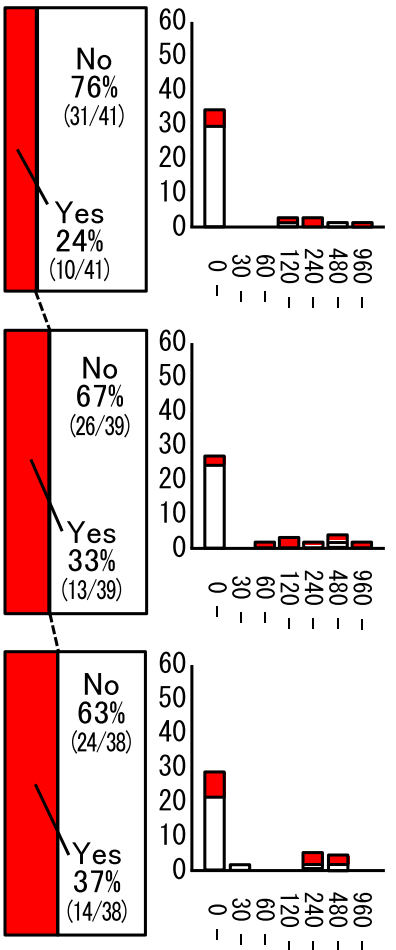

b

\section{2 years}

Age at 0 w: 44 or less

Age at 0 w: 45 or more
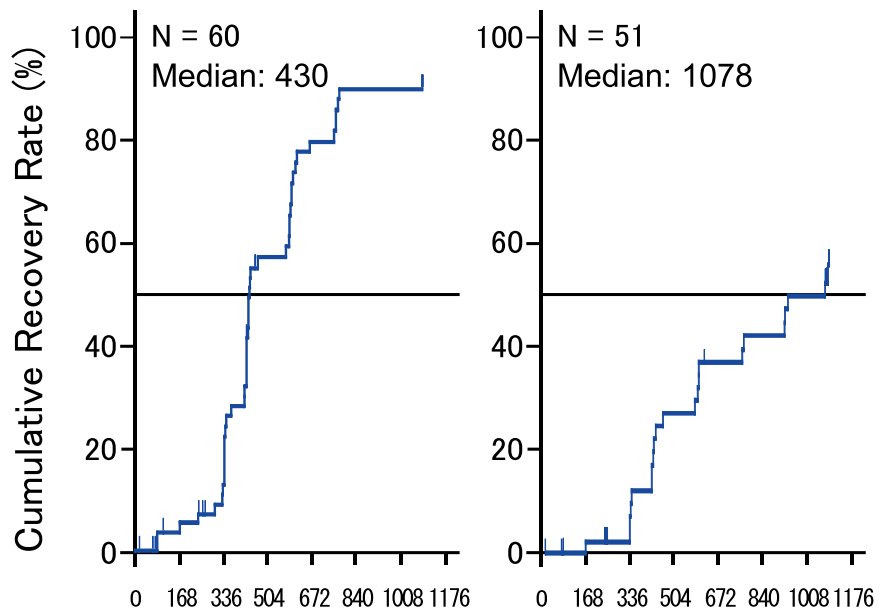

Recovery Period (Days)
Recovery Period (Days)

\section{3 or more years}

Age at 0 w: 44 or less

Age at $0 \mathrm{w}: 45$ or more

Menstruation E2 Histgram

Menstruation E2 Histgram
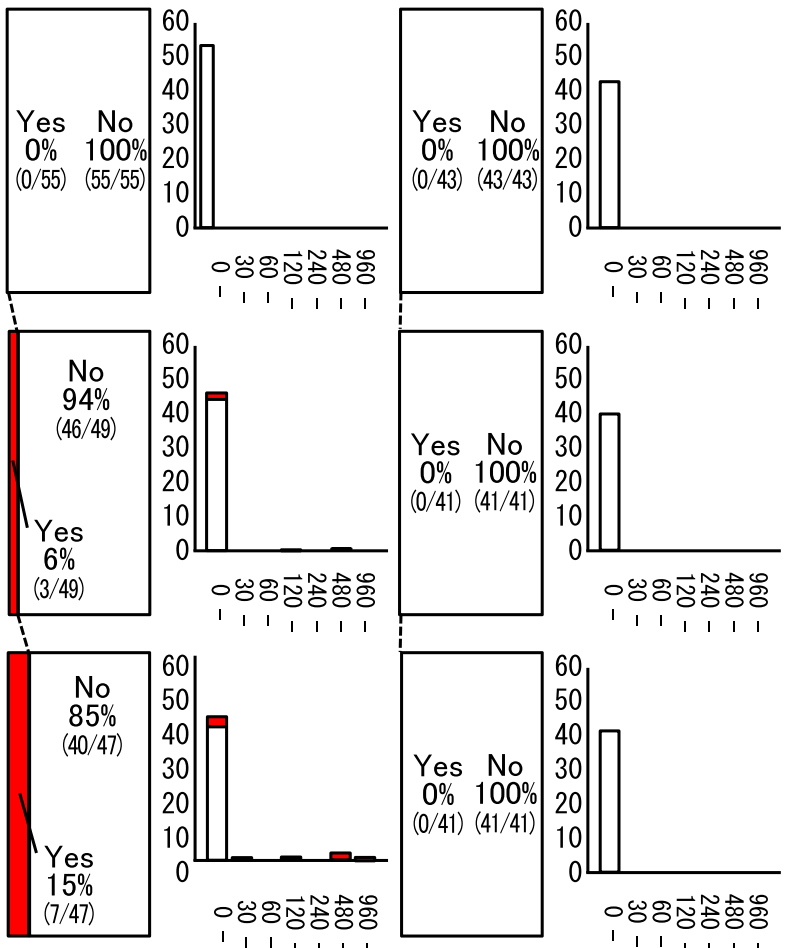

융즁중융
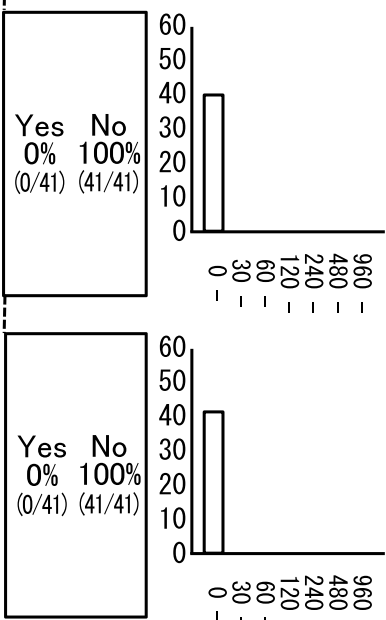

\section{3 or more years}

Age at 0 w: 44 or less $\quad$ Age at 0 w: 45 or more
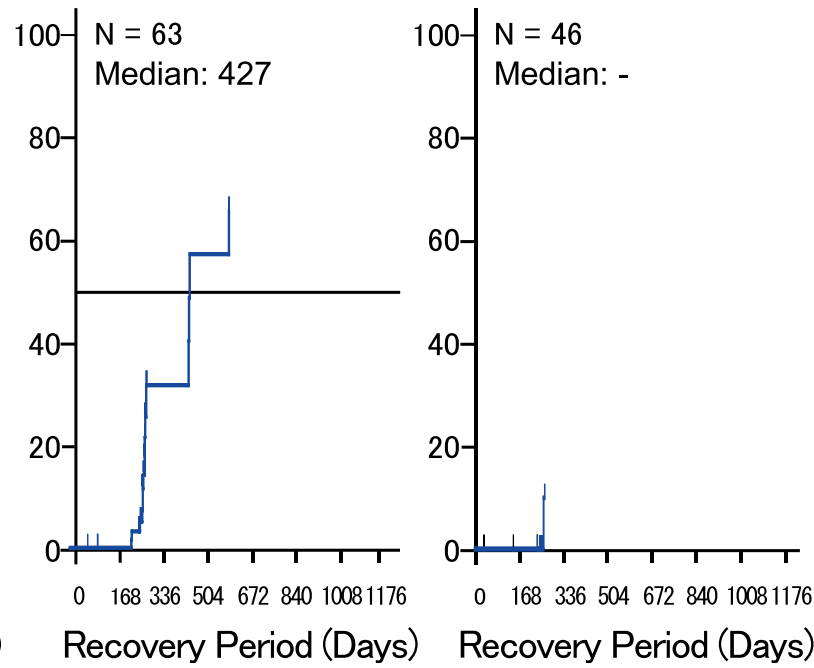

$0 \quad 16833650467284010081176$

Recovery Period (Days)

leuprorelin dosing to the first menstruation recovery was estimated by Kaplan-Meier method. $N$ number of patients evaluated, $144 w$ week 144, $192 w$ week 192, $240 w$ week 240 
Fig. 4 Multiple regression analyses for factor-quality of life (QOL) change relationship. Higher values mean better QOL [ES1 scale is inverted according to the QOL Questionnaire for Cancer Patients Treated with Anticancer Drugs-Breast (QOLACD-B) score]. Treatment groups $(1=2$ years; $0=3$ or more years). Age at week 0 multiplied by $(-1)$. QOL at week 96: QOLACD-B (item 13) or Functional Assessment of Cancer TherapyEndocrine Symptoms (FACT-ES) (ES1) at week 96 multiplied by $(-1)$. Menstruation (1, yes; 0 , no). $144 w$ week $144,192 w$ week 192, $240 w$ week 240

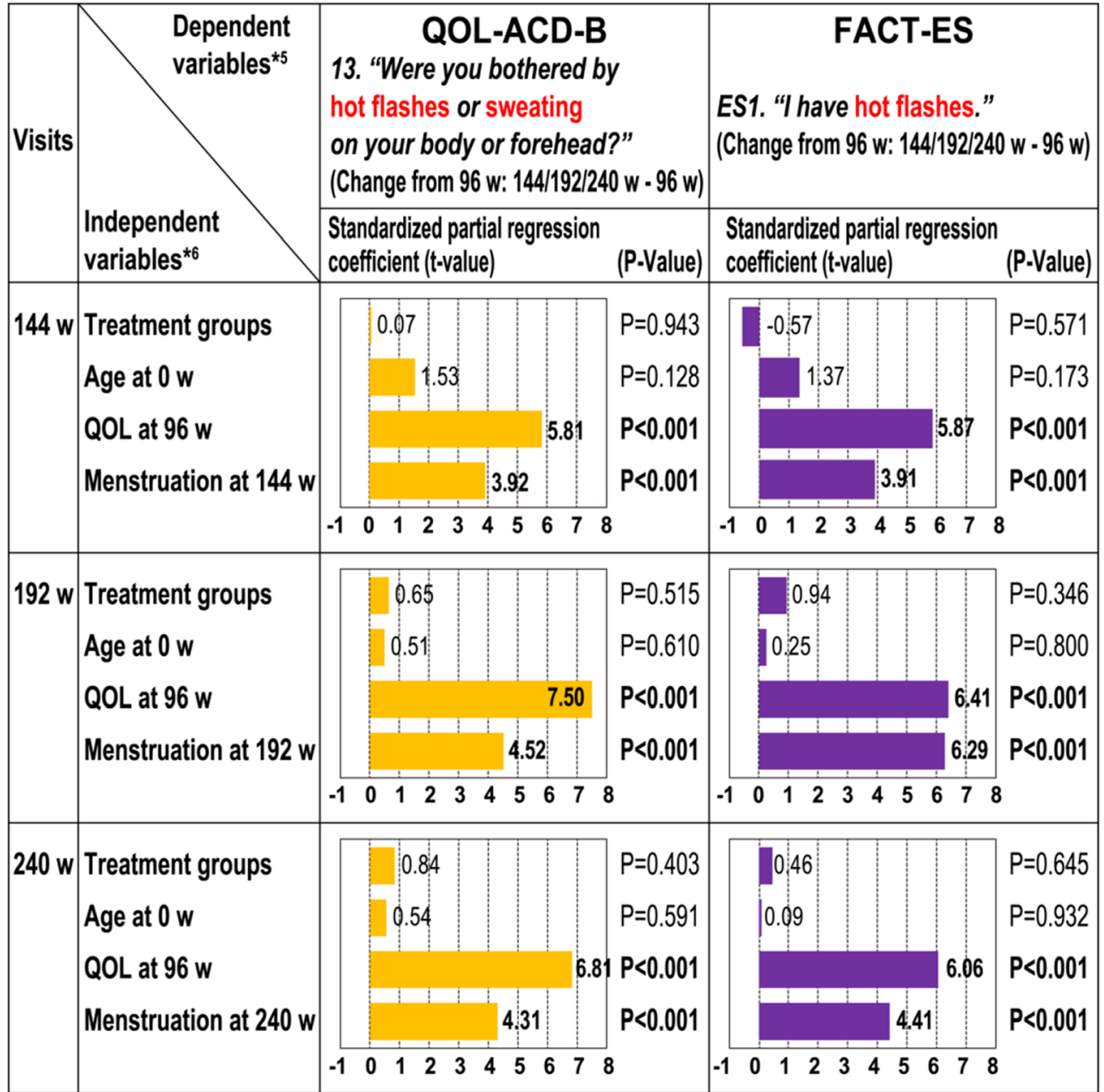

$\leq 44$ years in the $2 \mathrm{YG}$ at the same visits (Table 2), it also indicated that recovered menstruation after completion of treatment resulted in improvement of QOL concerning menopause-associated symptoms. The median time from last TAP-144-SR (3M) dosing to the first menstruation recovery by Kaplan-Meier estimation in the subpopulation aged $\leq 44$ years was 430 days in the $2 \mathrm{YG}$ and 427 days in the 3 YG (Fig. 3b), indicating that it took a similar number of days to recover menstruation in both groups. The above menstruation recovery results indicated that there were fewer patients with menstruation recovery in the $3 \mathrm{YG}$ than the $2 \mathrm{YG}$ during the 5 years ( 240 weeks). Such difference appears to be caused by the fact that a high proportion of patients in the $3 \mathrm{YG}$ received 20 doses of TAP-144-SR (3M), which is the maximum number of doses as specified in the protocol. Thus, the time to recover menstruation in the patient population aged $\leq 44$ years was similar irrespective of the treatment duration. On the other hand, in the $3 \mathrm{YG}$, there was only one patient with menstruation recovery during the follow-up observation in the patient population aged $\geq 45$ years, and other patients with menstruation recovery in this patient population were in the $2 \mathrm{YG}$. The median time from last TAP-144-SR (3M) dosing to the first menstruation recovery in the subpopulation aged $\geq 45$ years by Kaplan-Meier estimation was 1078 days in the $2 \mathrm{YG}$, indicating that it took a longer time to recover menstruation in comparison with the patient population aged $\leq 44$ years (Fig. 3b).

Evaluation of menstruation recovery is thought to be more appropriate to interpret the time from last TAP-144-SR (3M) dosing to the first menstruation recovery than the proportion of patients with recovered menstruation at each visit because the treatment duration of TAP-144-SR (3M) was different among patients in the $3 \mathrm{YG}$ due to the trial design. In addition, unlike other study endpoints, the recovery of menstruation was continuously monitored for an additional 36 weeks after the completion of the last dosing. However, the length of the total menstruation follow-up period (trial period after the last dosing and follow-up observation period) in the $2 \mathrm{YG}$ was longer than that in the $3 \mathrm{YG}$. Although the timing of recovery of menstruation after 5-year treatment in the patient population aged $\geq 45$ years in the $3 \mathrm{YG}$ is presumed to coincide with the timing of natural menopause in some patients, it could be evaluated better by conducting further follow-up investigations. 
Little is known about the impact of treatment on QOL in premenopausal breast cancer women receiving adjuvant hormone therapy; however, it is a major interest both for patients and clinicians [4]. A wide range of disease management based on QOL as well as other clinical presentation factors and individual patient conditions are necessary. In this study, the presence of menstruation contributed to provide significantly greater improvement in menopause-associated hot flashes and sweating burden in the $2 \mathrm{YG}$ than the $3 \mathrm{YG}$. $3 \mathrm{YG}$ showed a little, but not statistically significant, survival benefit (regarding DFS and OS), and comparable safety profiles and tolerability compared with $2 \mathrm{YG}$ in premenopausal endocrineresponsive breast cancer patients, and no new safety signals were identified [16]. Recently, the TEXT and SOFT trials demonstrated that 5-year adjuvant treatment with an aromatase inhibitor, exemestane, plus OFS significantly reduced recurrence compared to tamoxifen plus OFS [20]. The results of the SOFT trial further showed that adding 5-year OFS with an LH-RH agonist to 5-year tamoxifen did not provide a significant overall DFS benefit in the study population, but it was beneficial in patients, especially young patients aged $<35$ years at a high risk for recurrence who needed adjuvant chemotherapy and remained premenopausal despite chemotherapy [21]. In view of the coverage of health insurance in Japan, we had no choice but to select the concomitant use of tamoxifen with OFS to evaluate the optimal treatment duration with TAP-144SR (3M) in this trial. Given the results of the TEXT and SOFT trials, the addition of 5-year OFS with an LH-RH agonist to 5year tamoxifen should be similarly recommended to premenopausal patients at a high risk for recurrence in Japan. This trial was a pilot trial and the sample size was not sufficient to fully understand patients' QOL. Therefore, it should be further investigated in a larger population, but the use of TAP-144-SR (3M) for more than 2 years should be considered taking into account its potential impact on each patient's QOL as well as the risk for recurrence.

This trial provides clinicians with beneficial information regarding QOL effects and menstruation recovery with longterm treatment of TAP-144-SR in premenopausal patients with endocrine-responsive breast cancer. This information is widely applicable to premenopausal patients administered TAP-144-SR.

Acknowledgements We are grateful to all the patients, investigators, and clinical research coordinators who participated in this trial. Takeda Pharmaceutical Company Limited sponsored this trial, collected and analyzed the trial data, and gave medical editorial assistance with this manuscript. The trial centers are as follows: Department of Breast Surgery, Hokkaido Cancer Center; Department of Surgery, Sapporo Breast Surgery Clinic; Breast Surgery, Fukushima Medical University Hospital; Department of Surgery, Hoshi General Hospital; Breast and Endocrine Surgery, Gunma University Hospital; Department of Breast Oncology, Gunma Prefectural Cancer Center; Division of Breast Surgery, Saitama Cancer Center; Breast Center, International University of Health and Welfare, Mita Hospital; Department of Breast Oncology,
Juntendo University Hospital; Department of Breast and Endocrine Surgery, Tokai University Hospital; Department of Surgery, Yokohama Minami Kyosai Hospital; Department of Surgery, Shizuoka General Hospital; Department of Breast and Endocrine Surgery, Nagoya City University Hospital; Department of Breast and Endocrine Surgery, Osaka Medical Center for Cancer and Cardiovascular Diseases; Department of Breast and Endocrine Surgery, Osaka University Hospital; Department of Breast Surgery, Nakanoshima Osaka Breast Clinic; Department of Breast Surgery and Oncology, Hyogo Cancer Center; Department of Breast and Endocrine Surgery, Okayama University Hospital; and Department of Breast and Thyroid Surgery, Kawasaki Medical School. Editorial assistance in the preparation of this manuscript was provided by WysiWyg Co., Ltd., and financial support by Takeda Pharmaceutical Company Ltd.; the authors retained editorial control over the content.

\section{Compliance with ethical standards}

Conflict of interest Y. Ohashi received honoraria from Chugai Pharmaceutical Co., Ltd., Sanofi K.K., Shionogi Co., Ltd., and DaiichiSankyo Co., Ltd.; unspecified academic grants from Eisai Co., Ltd., and Yakult Honsya Co., Ltd.; and travel supports from Yakult Honsya Co., Ltd. and Takeda Pharmaceutical Co., Ltd., for international academic meetings; and is the chairman of the board of directors and owns stock of Statcom Co., Ltd. E. Shiba has nothing to disclose. H. Yamashita received research funding from Takeda Pharmaceutical Co., Ltd. J. Kurebayashi received advisory/consultation fees from Takeda Pharmaceutical Co., Ltd. and research funding from Takeda Pharmaceutical Co., Ltd., Eisai Co., Ltd., Chugai Pharmaceutical Co., Ltd., and AstraZeneca K.K. S. Noguchi received research funding from Takeda Pharmaceutical Co., Ltd., AstraZeneca K.K., Novartis Pharma K.K., Chugai Pharmaceutical Co., Ltd., Daiichi-Sankyo Co., Ltd., Pfizer Inc., Nippon Kayaku Co., Ltd., and Eisai Co., Ltd.; honoraria from Takeda Pharmaceutical Co., Ltd., AstraZeneca K.K., Novartis Pharma K.K., Chugai Pharmaceutical Co., Ltd., Daiichi-Sankyo Co., Ltd., Pfizer Inc., and Nippon Kayaku Co., Ltd.; and advisory fee from AstraZeneca K.K., Novartis Pharma K.K., and TAIHO Pharmaceutical Co., Ltd. H. Iwase received honoraria from AstraZeneca K.K., Novartis Pharma K.K., and Pfizer Inc.; and research funding from Takeda Pharmaceutical Co., Ltd., AstraZeneca K.K., Chugai Pharmaceutical Co., Ltd., TAIHO Pharmaceutical Co., Ltd., Eisai Co., Ltd., and Daiichi Sankyo Co., Ltd. M. Yoshida is an employee of Takeda Pharmaceutical Co., Ltd., and received stock dividends from Takeda Pharmaceutical Co., Ltd. T. Fujimoto is an employee of Takeda Pharmaceutical Co., Ltd.

Ethical approval This trial was conducted in accordance with the International Conference on Harmonization of Good Clinical Practice Guidelines, the principles of the Declaration of Helsinki, and all applicable laws and regulations at 19 medical centers in Japan between June 2006 and March 2013. The protocol was reviewed and approved by the institutional review boards of all participating trial sites.

Informed consent All patients provided written informed consent for participation before enrollment in the trial. Written informed consent was also obtained from patients who completed the treatment with TAP-144SR (3M) for 3 years in the $3 \mathrm{YG}$ and decided to extend the treatment.

Open Access This article is distributed under the terms of the Creative Commons Attribution-NonCommercial 4.0 International License (http:// creativecommons.org/licenses/by-nc/4.0/), which permits any noncommercial use, distribution, and reproduction in any medium, provided you give appropriate credit to the original author(s) and the source, provide a link to the Creative Commons license, and indicate if changes were made. 


\section{References}

1. Fallowfield LJ (1995) Assessment of quality of life in breast cancer. Acta Oncol 34:689-694

2. Fallowfield L (2005) Acceptance of adjuvant therapy and quality of life issues. Breast 14:612-616

3. Goodwin PJ, Black JT, Bordeleau LJ, Ganz PA (2003) Healthrelated quality-of-life measurement in randomized clinical trials in breast cancer - taking stock. J Natl Cancer Inst 95:263-281

4. Lemieux J, Goodwin PJ, Bordeleau LJ, Lauzier S, Thėberge V (2011) Quality-of-life measurement in randomized clinical trials in breast cancer: an updated systematic review (2001-2009). J Natl Cancer Inst 103:178-231

5. Whelan TJ, Pritchard KI (2006) Managing patients on endocrine therapy: focus on quality-of-life issues. Clin Cancer Res 12(3 Suppl):1056s-1060s

6. Perry S, Kowalski TL, Chang CH (2007) Quality of life assessment in women with breast cancer: benefits, acceptability and utilization. Health Qual Life Outcomes 5:24

7. Patterson RE, Saquib N, Natarajan L, Rock CL, Parker BA, Thomson CA, Pierce JP (2011) Improvement in self-reported physical health predicts longer survival among women with a history of breast cancer. Breast Cancer Res Treat 127:541-547

8. Goldhirsch A, Glick JH, Gelber RD, Senn HJ (1998) Meeting highlights: international consensus panel on the treatment of primary breast cancer. J Natl Cancer Inst 90:1601-1608

9. Jonat W, Kaufmann M, Sauerbrei W, Blamey R, Cuzick J, Namer M, Fogelman I, de Haes JC, de Matteis A, Stewart A, Eiermann W, Szakolczai I, Palmer M, Schumacher M, Geberth M, Lisboa B, Zoladex Early Breast Cancer Research Association Study (2002) Goserelin versus cyclophosphamide, methotrexate, and fluorouracil as adjuvant therapy in premenopausal patients with node-positive breast cancer: the Zoladex early breast cancer research association study. J Clin Oncol 20:4628-4635

10. Early Breast Cancer Trialists' Collaborative Group (EBCTCG) (2005) Effects of chemotherapy and hormonal therapy for early breast cancer on recurrence and 15-year survival: an overview of the randomised trials. Lancet 365:1687-1717

11. Schmid P, Untch M, Kossé V, Bondar G, Vassiljev L, Tarutinov V, Lehmann U, Maubach L, Meurer J, Wallwiener D, Possinger K (2007) Leuprorelin acetate every-3-months depot versus cyclophosphamide, methotrexate, and fluorouracil as adjuvant treatment in premenopausal patients with node-positive breast cancer: the TABLE study. J Clin Oncol 25:2509-2515

12. Klijn JGM, Blamey RW, Baccardo F, Tominaga T, Duchateau L, Sylvester R (2001) Combined tamoxifen and luteinizing hormonereleasing hormone (LHRH) agonist versus LHRH agonist alone in premenopausal advanced breast cancer: a meta-analysis of 4 randomized trials. J Clin Oncol 19:343-353

13. Goldhirsch A, Winer EP, Coates AS, Gelber RD, Piccart-Gebhart M, Thürlimann B, Senn HJ, Panel members (2013) Personalizing the treatment of women with early breast cancer: highlights of the St Gallen International Expert Consensus on the primary therapy of early breast cancer 2013. Ann Oncol 24:2206-2223

14. Goldhirsch A, Ingle JN, Gelber RD, Coates AS, Thürlimann B, Senn HJ, Panel members (2009) Thresholds for therapies: highlights of the St Gallen International Expert Consensus on the primary therapy of early breast cancer 2009. Ann Oncol 20:13191329

15. Goldhirsch A, Wood WC, Coates AS, Gelber RD, Thürlimann B, Senn HJ, Panel members (2011) Strategies for subtypes - dealing with the diversity of breast cancer: highlights of the St Gallen International Expert Consensus on the primary therapy of early breast cancer 2011. Ann Oncol 22:1736-1747

16. Shiba E, Yamashita H, Kurebayashi J, Noguchi S, Iwase H, Ohashi Y, Sasai K, Fujimoto T (2015) A randomized controlled study evaluating safety and efficacy of leuprorelin acetate every-3-months depot for 2 versus 3 or more years with tamoxifen for 5 years as adjuvant treatment in premenopausal patients with endocrineresponsive breast cancer. Breast Cancer (2016) 23:499-509

17. Kurihara M, Shimizu H, Tsuboi K, Kobayashi K, Murakami M, Eguchi K, Shimozuma K (1999) Development of quality of life questionnaire in Japan: quality of life assessment of cancer patients receiving chemotherapy. Psychooncology 8:355-363

18. The Japanese Breast Cancer Society (2002) Guidelines for quality of life assessment studies of breast cancer patients, Version 1.0. (in Japanese)

19. Fallowfield LJ, Leaity SK, Howell A, Benson S, Cella D (1999) Assessment of quality of life in women undergoing hormonal therapy for breast cancer: validation of an endocrine symptom subscale for the FACT-B. Breast Cancer Res Treat 55:189-199

20. Pagani O, Regan MM, Walley BA, Fleming GF, Colleoni M, Láng I, Gomez HL, Tondini C, Burstein HJ, Perez EA, Ciruelos E, Stearns V, Bonnefoi HR, Martino S, Geyer CE Jr, Pinotti G, Puglisi F, Crivellari D, Ruhstaller T, Winer EP, Rabaglio-Poretti M, Maibach R, Ruepp B, Giobbie-Hurder A, Price KN, Bernhard J, Luo W, Ribi K, Viale G, Coates AS, Gelber RD, Goldhirsch A, Francis PA, TEXT and SOFT Investigators; International Breast Cancer Study Group (2014) Adjuvant exemestane with ovarian suppression in premenopausal breast cancer. N Engl J Med 371: 107-118

21. Francis PA, Regan MM, Fleming GF, Láng I, Ciruelos E, Bellet M, Bonnefoi HR, Climent MA, Da Prada GA, Burstein HJ, Martino S, Davidson NE, Geyer CE Jr, Walley BA, Coleman R, Kerbrat P, Buchholz S, Ingle JN, Winer EP, Rabaglio-Poretti M, Maibach R, Ruepp B, Giobbie-Hurder A, Price KN, Colleoni M, Viale G, Coates AS, Goldhirsch A, Gelber RD, SOFT Investigators; International Breast Cancer Study Group (2015) Adjuvant ovarian suppression in premenopausal breast cancer. N Engl J Med 372: 436-446 